to the chair of chemistry in the Egyptian School of Medicine, Cairo; but his stay there was brief, and he returned to London in 1920 as professor of chemistry at Guy's Hospital Medical School. Here he was to remain until his retirement last September on reaching the age of sixty-five. During the Second World War he was senior gas adviser in south-eastern England.

Gibson's original work was largely influenced by his long collaboration with Pope. His main interest undoubtedly lay in the field of stereochemistry; but for a number of years after his return to England he devoted much attention to organic arsenic compounds, his interest in which had been aroused as a member of the Chemical Warfare Committee. In 1929, however, he returned to a problem which he had investigated earlier with Pope, namely, the organic compounds of gold. Here his great experimental skill enabled him to make contributions of outstanding importance, and few who visited his laboratory will forget the beauty of his gold mirrors, for which he devised a simple method of preparation. It was a profound disappointment to him that the anti-glare glasses which he made could not be used during the Second World War.

To the Chemical Society Gibson gave devoted service. He was honorary secretary during 1924-33 and a vice-president during 1933-36. In 1945, on the sudden death of the Society's editor, Dr. Clarence Smith, he, at considerable personal sacrifice, acted as editor for a number of months. He also took a great interest in the International Union for Pure and Applied Chemistry and was a member of the Organic Nomenclature Commission. In spite of failing health, he was able to attend the meeting in Amsterdam last September. On the formation in 1935 of the Society for the Protection of Science and Learning, Gibson and Sir William (now Lord) Beveridge were appointed secretaries. He also served on the councils of the Institute of Chemistry and the Royal Society of Arts. In his young days Gibson was an accomplished pianist; but he was never satisfied with his own performance, and latterly he gratified his love of music by listening to broadcasts.

Gibson's services to science did not pass unrecognized. He received the O.B.E. in 1919, and in 1931 he was elected a fellow of the Royal Society. $\mathrm{He}$ was the president of Section B (Chemistry) at the Cambridge meeting of the British Association in 1938, and was an honorary member of the Société de Chimie Industrielle. Many of his former students at Cambridge and Guy's Hospital will recall his many acts of kindness, not infrequently accompanied by financial assistance. He was unmarried.

$$
\text { J. L. STMONSEN }
$$

\section{Prof. George W. Todd}

George W. TODD, professor of experimental physics in King's College, Newcastle upon Tyne, died at his home in Ponteland, Northumberland, on February 24, after an operation. $\mathrm{He}$ had been in ill-health for some time.

Born in Birmingham in 1886, he was educated in that city and proceeded to the University in 1904. He graduated with honours in physics in 1907 and for the next two years worked under Prof. Poynting, with whom, jointly, he published his first paper, "On a Method of Determining the Sensibility of a Balance". In 1909 he went to Emmanuel College, Cambridge, as an 1851 Exhibition research scholar, and worked at the Cavendish Laboratory under Sir J. J. Thomson until 1912. The results of his work here on the mobility of gaseous ions are published in a series of papers in the Proceedings of the Cambridge Philosophical Society and Philosophical Magazine. During 1913-16 he held the appointment of science master at the Royal Grammar School, Newcastle upon Tyne. He became adviser in physics to the Nitrogen Products Committee of the Ministry of Munitions in 1916, and in 1917 was appointed head of the Physics Section, Munitions Inventions Department Laboratories, London. Here he carried out researches on nitrogen fixation processes. In 1919 he was appointed professor of experimental physics in Armstrong College (now King's College), Newcastle upon Tyne, an appointment which he held until his death. He had received the degrees of D.Sc. (Birmingham) in 1913 and M.Sc. (Dunelm) in 1920.

The bulk of Prof. Todd's published work was done between 1909 and 1922, and consists of papers on thermal conductivity, ionic mobilities, gas reactions and properties of gases. Shortly before his death, he edited Poynting and Thomson's "Properties of Matter". His teaching was noteworthy for clear and simple exposition. He made use of only the simplest mathematical technique, and his methods were those of the 'Poynting and Thomson' school. He was interested in devising new laboratory experiments, and nothing gave him greater pleasure than a novel idea or an original experimental device or method.

Prof. Todd found in gardening a congenial relaxation from academic work until ill-health intervened, and he was an enthusiastic member of the Newcastle Society of Artists, of which he was chairman. He got the same kind of æsthetic pleasure from drawing anc painting and looking at pictures as he derived from a study of physics. A few weeks before his last illness he was elected chairman of the recently formed North-Eastern Branch of the Institute of Physics, of which he was a founder fellow. His old students, who remember his modesty and kindliness, will deeply deplore his death.

He leaves a widow and married daughter.

J. F. WooD

\section{Mr. R. Kirkpatrick}

RANDOLPH KIRKPaTRICK, who died on March 16, was assistant keeper in the British Museum (Natural History) from September 1886 until his retirement on January 20,1927 . Originally intending to take up a medical career, he passed through Christ's Hospital and King's College Schools to become a medical student at St. George's Hospital, London, but illhealth determined him to "take up a less strenuous career". Ironically, he not only lived to be eightyseven and enjoyed excellent health for the greater part of this time, but also managed to crowd into his forty years service at the Museum a very great deal of scientific work. In addition, his wanderings took him to many parts of Europe, Asia and Africa, often to the more inaccessible regions, in search of scientific materials. Finally, he continued to ride his bicycle through the busy London streets until within a few months of his death.

Kirkpatrick's published works do not form an impressive total, though what he did publish was of high quality. On the other hand, the collections that were in his charge-and for the greater part of his time these included the Protozoa, Sponges, Colenterates, Polyzoa and Protochordates-were left in 
excellent order. $\mathrm{He}$ has been described by those who knew him well as the ideal public servant. Unassuming to a fault, courteous and generous, he would spare no effort to help either a colleague or a visiting student. It was in all probability his extreme willingness to interrupt whatever he was doing to help others that prevented his completing his work on Merlia normani and Astrosclera willeyana. It is clear that these were to have been dealt with in monographic proportions, and a set of beautiful plates had been prepared on Merlia but no notes.

For the last thirty years or so of his life, Kirkpatrick had followed what he ultimately saw to be a will-o'-the-wisp, a theory concerning the structure of the earth. His preliminary results are embodied in the four numbers of the Nummulosphere, which he had privately printed, and in a vast collection of rock specimens, collected and prepared at his personal expense. In later years, he confessed in private conversation that he had been misled, that what he had been seeing all the time but failing to recognize was what he called the "architecture of protoplasm". Perhaps he was right; at least his tentative suggestions seemed reasonable; but he died without leaving any permanent record of what his mature ideas might have been.

M. BURTON

\section{Prof. W. Fitzgerald}

Walter Fitzgerald was born at Liverpool in 1898 and died at Stockport on November 29, 1949. Partly of Irish extraction, he was temperamentally akin to many people of Anglo-Irish stock; for he had much of their charm of manner and ready humour, and not a little of their capacity for enjoyment. He constantly, if not always wisely, refused to submit to limitations of physical strength and always hoped for ultimate improvement: he had planned a three-months visit to Africa from December 1949 to March 1950, during which he was to travel in Basutoland.

A graduate of the University of Liverpool with first-class honours in geography, Fitzgerald was one of a group of ex-Service men brought under the spell of Prof. P. M. Roxby's great oratorical and teaching powers. The powerful personality of Roxby proved an abiding influence; but Fitzgerald had too much independence of mind to accept uncritically any one man's work. He derived his unusual interest in international affairs and social problems partly from the teaching at Liverpool and partly from his innate sympathy of mind; and his last published work, "The New Europe" (1945), was a welcome contribution to political geography. A similar interest was seen in his larger work, "Africa" (1934), which is still the major English text-book on the subject and in its sixth edition. It was the monograph on "The Early Historical Geography of Ireland", published in 1926 by the Geographical Association, that first brought his name to readers, who admired both its clear regional treatment and its interpretation of archæological material; since then, it has become a commonplace for archæologists to use distribution maps ; but the maps of this book are superseded only for the happy reason that archæologists in Ireland have added so much new material. He saw particularly the need for geographers to think out the exact nature of their work, and published three short articles in Nature $(152,589,740 ; 153,481)$ to define his attitude. He had a strong interest in what is now termed 'methodology' and gave stimulating lectures on the general content of the subject.

Apart from a year (1924-25) at Pretoria, Walter Fitzgerald spent his whole working life in the University of Manchester, where he joined the staff in 1925 as lecturer ; he later became senior lecturer and in 1944 he succeeded Prof. H. J. Fleure as professor. The work of running a large and growing department, in which there were ten or more applicants for every possible place, proved a severe strain to one always cautious in decision and eager to continue his own researches in spite of administrative duties. His life was marked by sorrow as well as indifferent health, and his work on "The New Europe" was dedicated to the memory of his baby daughter. $\mathrm{He}$ is survived by $\mathrm{a}$ widow and one young son. T. W. Freeman

\section{NEWS and VIEWS}

\section{Metallurgy at Sheffield: Prof. A. G. Quarrell}

DR. A. G. QUARRELI, research manager to the British Non-Ferrous Metals Research Association, has been appointed to the new chair of postgraduate physical metallurgy in the University of Sheffield. Dr. Quarrell, who is thirty-nine years of age, received his scientific education at the Imperial College of Science and Technology, London, graduating in 1931 with honours in physics. During 1931-36 he undertook research on electron diffraction problems in conjunction with Prof. G. I. Finch. In 1937 he was appointed assistant lecturer in metallurgy in the University of Sheffield and was raised to the status of full lecturer in 1940. While at Sheffield, Dr. Quarrell undertook a variety of research work, most of which has been published in the Journal of the Iron and Steel Institute. In particular, this dealt with hydrogen in iron and its influence on hair-line crack formation. He also carried out further work with an electron diffraction camera, examining the transformations in iron oxide during cooling from high temperatures. Another notable piece of work was his laboratory investigation of the phosphorus reaction in the basic steel-making processes. In 1945 he went to the British Non-Ferrous Metals Research Association. It is expected that Dr. Quarrell will take up his new post in Sheffield in October.

\section{Physiology at Madrid : Dr. F. Grande}

Dr. Francisco Grande has recently been elected professor of physiology in the University of Saragossa. This is a necessary preliminary to the appoint. ment to the chair of physiology in the University of Madrid, and the formalities are made in this way because it is considered that anyone appointed to so important a chair as that at Madrid should be already a professor at one of the lesse universities. Upon appointment at Saragossa, the new professor pays a formal visit lasting a few days to 'take office', after which his official duties at Saragossa may terminate. The election to the chair at Saragossa still takes the form of a public contest, as was usual at most universities in medieval times. In this case the seven selected candidates are required to give two lectures, one of which must be given impromptu on a subject 